\title{
Barley Traits Associated with Resistance to Fusarium Head Blight and Deoxynivalenol Accumulation
}

\author{
Thin Meiw Choo, Bernard Vigier, Qiu Quan Shen, Richard A. Martin, Keh Ming Ho, and Marc Savard
}

First, second, fifth, and sixth authors: Eastern Cereal and Oilseed Research Centre, Agriculture and Agri-Food Canada, Ottawa, Ontario K1A 0C6, Canada; third author: Zhejiang Academy of Agricultural Sciences, Hangzhou, Zhejiang 310021, China; and fourth author: Crops and Livestock Research Centre, Agriculture and Agri-Food Canada, Charlottetown, Prince Edward Island C1A 4N6, Canada. Accepted for publication 8 June 2004.

\begin{abstract}
Choo, T. M., Vigier, B., Shen, Q. Q., Martin, R. A., Ho, K. M., and Savard, M. 2004. Barley traits associated with resistance to Fusarium head blight and deoxynivalenol accumulation. Phytopathology 94:1145-1150.

Fusarium head blight (FHB) or scab is a destructive disease of barley in many countries. A better understanding of the interrelationships between plant traits and FHB resistance should help in the development of effective and efficient breeding strategies for FHB-resistant cultivars. Recent mapping studies indicate that many of the quantitative trait loci (QTL) for FHB resistance coincide with the QTL for plant height, heading date, and spike characteristics. Therefore, a study was conducted to investigate the relationship of morphological and physiological traits to FHB infection and deoxynivalenol (DON) accumulation in a barley doubled-haploid $(\mathrm{DH})$ population derived from a Léger $\times$ CI9831 cross.

Charlottetown (Prince Edward Island) for 1 year, and Hangzhou (Zhejiang) for 2 years. The field plots were inoculated with Fusarium graminearum at each location. FHB incidence was positively correlated with DON content. Resistance to FHB was associated with two-row spike, purple lemma, long glume awn, tall stature, and resistance to lodging, but it was not associated with long rachilla hairs, rough lemma awn, or heading date. Two-row spike was associated with tall stature and resistance to lodging. These associations as well as its spike characteristics helped reduce FHB infection and DON accumulation in two-row lines compared with six-row lines. The association between long glume awn and FHB resistance could be due to genetic linkages. Therefore, trait associations should be taken into consideration when breeding for FHB resistance and interpreting data from FHB experiments.
\end{abstract} Approximately $190 \mathrm{DH}$ lines were grown at Ottawa (Ontario) for 2 years,
Additional keyword: Hordeum vulgare.
Fusarium head blight or scab is a destructive disease of barley (Hordeum vulgare) in many warm, humid growing regions of the world. It is caused by Fusarium species, particularly F. graminearum. The fungi produce such mycotoxins as deoxynivalenol (DON), nivalenol (NIV), and zearalenone (1). These mycotoxins, in turn, can be harmful to animal and human health. Therefore, measures to reduce mycotoxin contamination are needed in barley. A better understanding of the interrelationships between plant traits and FHB resistance should be useful in the development of effective and efficient breeding strategies for FHB-resistant cultivars and for data interpretation of FHB experiments.

Several traits of barley have been reported to have a strong influence on the level of FHB infection and DON contamination. Some traits show a consistent relationship to FHB infection and DON accumulation over a wide range of environments and genetic backgrounds, while others do not show any consistent relationship. Tall plants are usually more resistant to FHB than short plants and thus their seeds contain less DON $(5,13,21)$. Heading date, however, can be either negatively $(5,13,15,20)$ or positively $(5,13,15)$ correlated with DON content depending upon environmental conditions and inoculation methods. Spike characteristics also play a major role in FHB infection and DON contamination. Between the two spike types, distichon two-row (vrsl.b) is more resistant to FHB than six-row (vrsl.a) $(2,15,20)$. But more resistance to FHB does not always result in lower DON content for two-row barley. For example, Chełkowski et al. (2) found that

Corresponding author: T. M. Choo; E-mail address: chootm@agr.gc.ca

Publication no. P-2004-0823-02R

This article is in the public domain and not copyrightable. It may be freely reprinted with customary crediting of the source. The American Phytopathological Society, 2004 two-row doubled-haploid (DH) lines contain similar amounts of NIV and DON content as six-row lines. Lax and nodding spike may or may not be associated with resistance to FHB and DON accumulation $(13,20,21)$. Infertile lateral florets (int-c) were associated with FHB resistance and DON content in one population (21), but not in another population (15). The higher the number of seeds per spike, the better is the resistance to FHB and DON accumulation (21). Rough lemma awn (Rawl) appears to have no effect on the level of DON content (20). More significant, many quantitative trait loci (QTL) for FHB resistance and DON accumulation coincide with QTL for heading date, plant height, and spike characteristics in several mapping populations $(5,13,15,21)$.

We have derived DH lines from a Léger $\times$ CI9831 cross and these DH lines differ with respect to many traits $(3,4,7-10)$. They are ideal material for trait association studies. Therefore, a study was conducted to investigate the relationship of two-row, purple lemma, long rachilla hairs, rough lemma awn, long glume awn, plant height, heading date, and lodging to FHB infection and DON accumulation in this DH population.

\section{MATERIALS AND METHODS}

Artificial inoculation tests. One hundred and ninety DH lines were derived from a Léger $\times$ CI9831 cross. Léger is a six-row cultivar with yellow lemma, short rachilla hair, smooth lemma awn, and short glume awn (Table 1). In contrast, CI9831 is a tworow accession with purple lemma, long rachilla hair, rough lemma awn, and long glume awn. These DH lines, along with the two parents, were planted in four replicates at Ottawa (Ontario) in 2001, two replicates in Ottawa in 2002, two replicates in Charlottetown (Prince Edward Island) in 2002, four replicates at Hangzhou (Zhejiang) in the winter of 2000 to 2001, and two 
replicates at Hangzhou in the winter of 2001 to 2002. In each replicate, each parent was entered five times at Ottawa and Charlottetown and twice at Hangzhou. Data were analyzed as a randomized complete block design for all three locations.

At Ottawa, the experimental material was seeded on 3 May 2001 and on 9 and 13 May 2002 at a seeding rate of 5 g per row. Each experimental plot consisted of two $1.5-\mathrm{m}$ rows with a row spacing of $15 \mathrm{~cm}$. Three $F$. graminearum isolates were used as inoculum for this study: DAOM178148, DAOM212678, and AC Taho. They were originally collected from wheat plants in Ontario. Equal parts by volume of corn and barley grain were mixed and soaked in water for $48 \mathrm{~h}$. Excess water was removed and the kernel mixture, which was placed in an aluminum pan $(53 \times 32 \times$ $8 \mathrm{~cm}^{3}$ ) and covered with two layers of aluminum foil, was autoclaved for $1 \mathrm{~h}$ at $120^{\circ} \mathrm{C}$. In each pan, $100 \mathrm{ml}$ of spore suspension of individual isolates at a concentration of $5.5 \times 10^{4}$ spores $\mathrm{ml}^{-1}$ was evenly poured over the surface of the kernel mixture in a laminar flow hood. The kernel mixture was incubated at room temperature for at least 4 weeks. Kernels infected with the three isolates were mixed in the same proportion and then broadcast at a rate of $30 \mathrm{~g} \mathrm{~m}^{-2}$ twice in 2001 ( 6 and 15 June), and twice in 2002 (13 and 20 June). The plots were watered with a sprinkler system twice a day (at 11:00 to 11:30 a.m. and 3:00 to 4:00 p.m.) for 20 to $30 \mathrm{~min}$ to increase the humidity. Heading date, plant height, and FHB incidence (percentage of heads infected per row) were recorded. Approximately 20 to $25 \mathrm{~g}$ of harvested barley seed was ground to pass through a $0.4 \mathrm{~mm}$ screen on a Udy-Mill (Udy Corporation, Fort Collins, CO). To prepare extracts, $5 \mathrm{ml}$ of methanol/water $(1: 9, \mathrm{vol} / \mathrm{vol})$ was added to 1 -g ground samples in 10 -ml plastic tubes, which were then subjected to end-over-end mixing for $1 \mathrm{~h}$ and centrifuged for $5 \mathrm{~min}$ at 2,000 rpm. DON analysis was conducted on the filtrate following the enzymelinked immunosorbent assay (ELISA) procedures described by Sinha et al. (17). The accuracy of the ELISA procedures has been reported to be comparable to that of the gas chromatography method (16). The limit of quantitation was $0.1 \mathrm{mg} \mathrm{kg}^{-1}$. Any samples with less than $0.1 \mathrm{mg} \mathrm{kg}^{-1}$ of DON were considered as having a zero concentration of DON.

At Charlottetown, the experimental material was seeded on 24 May 2002 at a seeding rate of $3 \mathrm{~g}$ per row. Each experimental plot consisted of one $0.5-\mathrm{m}$ row with a row spacing of $20 \mathrm{~cm}$. The plots were sprayed with a conidial suspension of five $F$. graminearum isolates $\left(50,000\right.$ spores $\left.\mathrm{ml}^{-1}\right)$ at a rate of 125 liters ha ${ }^{-1}$. The five isolates were collected from wheat and barley plants in Prince Edward Island. The inoculum was applied three times (at heading, 7 days after heading, and 14 days after heading). The plots were watered with a sprinkler system for 2 min every 30 min from heading to hard dough stage. Heading date was recorded in each plot. DON content was determined for each plot following the procedures described earlier.

TABLE 1. Classification of 190 barley doubled-haploid (DH) lines derived from a Léger $\times$ CI9831 cross into 10 marker classes on the basis of five morphological markers

\begin{tabular}{lcccc}
\hline & & & \multicolumn{2}{c}{ No. of DH lines } \\
\cline { 3 - 5 } Trait & Locus & Chromosome & $\begin{array}{c}\text { Léger } \\
\text { genotype }^{\mathrm{x}}\end{array}$ & $\begin{array}{c}\text { CI9831 } \\
\text { genotype }^{\mathrm{y}}\end{array}$ \\
\hline Row type & Vrs 1 & $2 \mathrm{H}$ & 95 & 95 \\
Lemma color & Pre2 & $2 \mathrm{H}$ & 91 & 99 \\
Rachilla hairs & Srh & $5 \mathrm{H}$ & 91 & 99 \\
Lemma awn & Raw1 & $5 \mathrm{H}$ & 92 & 97 \\
Glume awn & Lga & $7 \mathrm{H}$ & 77 & 116 \\
\hline
\end{tabular}

${ }^{x}$ Léger carries the Vrs1.a (six-row), pre2 (yellow lemma), Srh (short rachilla hairs), raw1 (smooth lemma awn), and lga (short glume awn) alleles.

${ }^{y}$ CI9831 carries the vrs1.t (two-row), Pre2 (purple lemma), srh (long rachilla hairs), Raw1 (rough lemma awn), and $L g a$ (long glume awn) alleles.

${ }^{\mathrm{z}}$ Distorted segregation because the observed segregation ratio 116 (long):77 (short) was deviated from the expected 1:1 ratio $\left(\chi^{2}=7.5, P<0.01\right)$.
At Hangzhou, the experimental material was seeded on 9 December 2000 and 14 November 2001 at a seeding rate of $5 \mathrm{~g}$ per row. Each plot consisted of one 0.2-m row with a row spacing of $33 \mathrm{~cm}$. A mixture of $F$. graminearum isolates collected from cv. Giu Damai from Hailing, Zhejiang was multiplied on potato dextrose agar medium for 10 days. Wheat kernels were soaked in water for $24 \mathrm{~h}$, put in 1-liter glass bottles, and autoclaved for $30 \mathrm{~min}$ at $120^{\circ} \mathrm{C}$. The wheat kernels were inoculated with the $F$. graminearum mycelium at five positions in a glass bottle and incubated at $25^{\circ} \mathrm{C}$ for 10 days. Infected wheat kernels were broadcast at a rate of $7.5 \mathrm{~g} \mathrm{~m}^{-2}$ at the booting stage. At heading, the plots were also sprayed with an $F$. graminearum suspension (4,000 spores per $\mathrm{ml}$ ). Plant height, heading date, and FHB symptoms were recorded for each plot. FHB symptoms were rated on 30 heads with two methods: FHB incidence and FHB severity. For FHB severity, heads were each classified into five classes based on visual symptoms: resistant (no infection), moderately resistant (less than $25 \%$ of the seeds infected), moderately susceptible (25 to $50 \%$ of the seeds infected), susceptible (50 to $75 \%$ of the seeds infected), and highly susceptible (more than $75 \%$ of the seeds infected). The five classes of heads were assigned a score ranging from 0 to 4 with 0 being no infection. FHB severity was the average score weighted for the number of heads per class and expressed in percentage of the worst score (i.e., 4).

Statistical analysis. Differences between the two parents and between the mean of the two parents and the mean of all DH lines were tested by an $F$ test. Trait associations were studied by two different approaches: marker-based analysis and trait-based analysis (12). For the marker-based analysis, the means of two marker classes for each qualitative trait (i.e., two-row versus sixrow, purple lemma versus yellow lemma, long rachilla hairs versus short rachilla hairs, rough lemma awn versus smooth lemma awn, and long glume awn versus short glume awn) were compared at each location in each year by testing the between classes mean square against the within classes mean square with an $F$ test. The least significant difference (LSD) was used to compare the means of four marker classes of DH lines (19). The

TABLE 2. Means for 190 barley double-haploid (DH) lines ${ }^{\mathrm{x}}$ derived from a Léger $\times$ CI9831 cross grown in five tests that were inoculated with Fusarium graminearum

\begin{tabular}{lccccc}
\hline & & & & \multicolumn{2}{c}{ DH lines } \\
\cline { 5 - 6 } Trait & Test & Léger & CI9831 & Mean & Range \\
\hline Heading (days) & OT2001 & $52 \mathrm{a}^{\mathrm{y}}$ & $55 \mathrm{~b}$ & 54 & $46-61$ \\
& OT2002 & $54 \mathrm{a}$ & $52 \mathrm{~b}$ & 53 & $47-59$ \\
& CH2002 & $51 \mathrm{a}$ & $49 \mathrm{~b}$ & 51 & $45-56$ \\
& HZ2001 & $125 \mathrm{a}$ & $119 \mathrm{~b}$ & 123 & $115-132$ \\
& HZ2002 & $143 \mathrm{a}$ & $137 \mathrm{~b}$ & 140 & $124-154$ \\
Height (cm) & OT2001 & $119 \mathrm{a}$ & $120 \mathrm{a}$ & 122 & $99-144$ \\
& OT2002 & $93 \mathrm{a}$ & $104 \mathrm{~b}$ & 97 & $70-122$ \\
& HZ2001 & $116 \mathrm{a}$ & $117 \mathrm{a}$ & 117 & $94-142$ \\
Lodging (0-9) & HZ2002 & $99 \mathrm{a}$ & $103 \mathrm{a}$ & 101 & $74-117$ \\
& OT2001 & $0.6 \mathrm{a}$ & $5.0 \mathrm{~b}$ & 3.0 & $0.0-8.3$ \\
FHB incidence (\%) & OT2002 & $0.2 \mathrm{a}$ & $0.2 \mathrm{a}$ & 0.3 & $0.0-4.5$ \\
& OT2001 & $15 \mathrm{a}$ & $6 \mathrm{~b}$ & 13 & $0-37$ \\
& OT2002 & $47 \mathrm{a}$ & $3 \mathrm{~b}$ & 17 & $0-57$ \\
FHB severity (\%) & HZ2001 & $98 \mathrm{a}$ & $21 \mathrm{~b}$ & 69 & $16-100$ \\
& HZ2002 & $97 \mathrm{a}$ & $43 \mathrm{~b}$ & 67 & $3-100$ \\
DON (mg kg & HZ2001 & $31 \mathrm{a}$ & $5 \mathrm{~b}$ & 22 & $4-44$ \\
& HZ2002 & $24 \mathrm{a}$ & $3 \mathrm{~b}$ & 18 & $1-52$ \\
& OT2001 & $5 \mathrm{a}$ & $3 \mathrm{~b}$ & 8 & $0-118$ \\
& OT2002 & $10 \mathrm{a}$ & $1 \mathrm{~b}$ & 5 & $1-31$ \\
& CH2002 & $26 \mathrm{a}$ & $11 \mathrm{~b}$ & 16 & $4-56$ \\
\hline
\end{tabular}

x 190 lines at Ottawa in 2001 (OT2001), at Ottawa in 2002 (OT2002), at Charlottetown in 2002 (CH2002); 189 lines at Hangzhou in 2001 (HZ2001); and 181 lines at Hangzhou in 2002 (HZ2002).

${ }^{y}$ Means followed by different letters for each trait in each test are significantly different at $P=0.05$ based on the $F$ test.

${ }^{\mathrm{z}} 0=$ no lodging, $9=$ severe lodging. 
significance of the Pearson correlations between quantitative traits was determined. Correlations were calculated by using the mean of each DH line at each location in each year. The DON data were transformed into logarithms to stabilize the variance and then the transformed data were used for analysis of variance, LSD test, and correlation analysis. Untransformed DON data, however, were presented. For the trait-based analysis, the top and the bottom $10 \%$ of the lines were selected on the basis of DON content (Ottawa and Charlottetown) or FHB incidence (Hangzhou). In the absence of association, the frequency of two-row, purple lemma, long rachilla hairs, and rough lemma awn is expected to be $50 \%$ and that of long glume awn $60 \%$ (Table 1). In the absence of association, the means of quantitative traits between these two selected groups should be equal. Differences in frequencies for qualitative traits between the two selected groups were tested by a $\chi^{2}$ test, and differences in means for quantitative traits between the two selected groups by a $t$ test.

\section{RESULTS}

The two-row parent CI9831 generally headed earlier and was more susceptible to lodging than the six-row parent Léger (Table 2). Also, CI9831 was more resistant to FHB and DON accumulation. The mean of the two parents was similar to that of all DH lines for the six traits $(P=0.05)$ (Table 2$)$.

Marker-based analysis. Two-row lines headed earlier than six-row lines at Hangzhou, they were also taller and more resistant to lodging than six-row lines (Table 3). On average, tworow lines were more resistant to FHB and DON accumulation than six-row lines in all five tests (Table 3 ). In fact, six-row lines contained 0.7 to 3.4 times more DON than two-row lines. Long glume awn was associated with low FHB incidence and low DON content at Ottawa in both years (Table 3). It was also associated with low DON content at Charlottetown in 2002 and low FHB severity at Hangzhou in both years. The differences for the six traits between purple and yellow lemma were very similar to those between two-row and six-row spike because these two loci are closely linked (recombination value $=0.11$ ) on chromosome $2 \mathrm{H}$ (10). Therefore, these two traits should be studied simultaneously. Purple lemma was associated with reduced FHB incidence in three of the four tests and reduced FHB severity in the two tests at Hangzhou, particularly for the two-row type (Table 4). The reduction in FHB incidence, however, did not result in lower DON content for purple barley.

The means of long rachilla hairs did not differ from those of short rachilla hairs for the six traits in all five tests, except at Charlottetown where long rachilla hairs were associated with low DON content (data not shown). Likewise, the means of rough awn did not differ from those of smooth awn for the six traits in any of the five tests (data not shown).

Heading date was not significantly correlated with DON content or FHB incidence for either two-row or six-row lines in any of the five tests, except at Charlottetown where heading date was positively correlated with DON content in six-row barley (Table 5). All four correlation coefficients between plant height and DON content at Ottawa were significantly negative, while only one of the four correlation coefficients between plant height and FHB incidence at Hangzhou was negative (Table 5). Lodging resistance was positively correlated with DON content for each spike type at Ottawa (Table 5). FHB incidence was positively correlated with DON content for both spike types at Ottawa in both years (Table 5).

Trait-based analysis. Most of the DH lines in the resistant group had two-row spike, purple lemma, and long glume awn (Table 6). The most resistant lines were generally tall and resistant to lodging. In contrast, most of the $\mathrm{DH}$ lines in the susceptible group had six-row spike, yellow lemma, and short glume awn. The most susceptible lines were short and susceptible to lodging. There was no difference between the two groups of selection lines in terms of the percentage of long rachilla hairs and rough lemma awn.

TABLE 3. Means of four types of barley doubled-haploid lines derived from a Léger $\times$ CI9831 cross grown in five tests that were inoculated with Fusarium graminearum

\begin{tabular}{|c|c|c|c|c|c|c|}
\hline Type & Heading (days) & Height $(\mathrm{cm})$ & Lodging $(0-9)^{\mathrm{v}}$ & FHB $^{\mathrm{w}}$ incidence $(\%)$ & FHB severity (\%) & $\operatorname{DON}^{x}\left(\mathrm{mg} \mathrm{kg}^{-1}\right)$ \\
\hline \multicolumn{7}{|l|}{ Ottawa 2001} \\
\hline Two-row spike & $54.1 \mathrm{a}^{\mathrm{y}}$ & $127 \mathrm{a}$ & $2.3 \mathrm{a}$ & $6.7 \mathrm{a}$ & $\ldots^{\mathrm{z}}$ & $3.9 \mathrm{a}$ \\
\hline Six-row spike & $53.4 \mathrm{a}$ & $116 \mathrm{~b}$ & $3.7 \mathrm{~b}$ & $19.6 \mathrm{~b}$ & $\ldots$ & $12.9 \mathrm{~b}$ \\
\hline Short glume awn & $52.8 \mathrm{~b}$ & $121 \mathrm{a}$ & $3.0 \mathrm{a}$ & $16.2 \mathrm{~b}$ & $\ldots$ & $10.5 \mathrm{~b}$ \\
\hline \multicolumn{7}{|l|}{ Ottawa 2002} \\
\hline Two-row spike & $53.1 \mathrm{a}$ & $102 \mathrm{a}$ & $0.1 \mathrm{a}$ & $6.3 \mathrm{a}$ & $\ldots$ & $2.8 \mathrm{a}$ \\
\hline Six-row spike & $53.4 \mathrm{a}$ & $93 \mathrm{~b}$ & $0.4 \mathrm{a}$ & $27.8 \mathrm{~b}$ & $\ldots$ & $7.2 \mathrm{~b}$ \\
\hline \multicolumn{7}{|l|}{ Charlottetown 2002} \\
\hline Two-row spike & $50.7 \mathrm{a}$ & $\ldots$ & $0.0 \mathrm{a}$ & $\ldots$ & $\ldots$ & $13.1 \mathrm{a}$ \\
\hline Six-row spike & $51.1 \mathrm{a}$ & $\ldots$ & $0.0 \mathrm{a}$ & $\ldots$ & $\ldots$ & $19.9 \mathrm{~b}$ \\
\hline Long glume awn & $51.1 \mathrm{a}$ & $\ldots$ & $0.0 \mathrm{a}$ & $\ldots$ & $\ldots$ & $15.4 \mathrm{a}$ \\
\hline Short glume awn & $50.6 \mathrm{a}$ & $\ldots$ & $0.0 \mathrm{a}$ & $\ldots$ & $\ldots$ & $18.1 \mathrm{~b}$ \\
\hline \multicolumn{7}{|l|}{ Hangzhou 2001} \\
\hline Two-row spike & $122 \mathrm{a}$ & $119 \mathrm{a}$ & $\ldots$ & $45.6 \mathrm{a}$ & $12.0 \mathrm{a}$ & $\ldots$ \\
\hline Two-row spike & $139 \mathrm{a}$ & $102 \mathrm{a}$ & $0.0 \mathrm{a}$ & $46.6 \mathrm{a}$ & $9.0 \mathrm{a}$ & $\ldots$ \\
\hline Six-row spike & $141 \mathrm{~b}$ & $100 \mathrm{~b}$ & $0.0 \mathrm{a}$ & $88.4 \mathrm{~b}$ & $27.9 \mathrm{~b}$ & $\ldots$ \\
\hline Long glume awn & $140 \mathrm{a}$ & $101 \mathrm{a}$ & $0.0 \mathrm{a}$ & $63.5 \mathrm{a}$ & $15.5 \mathrm{a}$ & $\ldots$ \\
\hline Short glume awn & $140 \mathrm{a}$ & $101 \mathrm{a}$ & $0.0 \mathrm{a}$ & $71.7 \mathrm{a}$ & $21.9 \mathrm{~b}$ & $\ldots$ \\
\hline
\end{tabular}

v $0=$ no lodging, $9=$ severe lodging.

${ }^{\mathrm{w}} \mathrm{FHB}=$ Fusarium head blight.

${ }^{x} \mathrm{DON}=$ deoxynivalenol content.

${ }^{y}$ Means for each trait at each location in each year followed by different letters are significantly different at $P=0.05$ based on the $F$ test.

${ }^{z}$ Not determined. 
TABLE 4. Means of four types of barley doubled-haploid lines derived from a Léger $\times$ CI9831 cross grown in five tests that were inoculated with Fusarium graminearum

\begin{tabular}{|c|c|c|c|c|}
\hline Type & $\begin{array}{l}\text { No. } \\
\text { of } \\
\text { lines }\end{array}$ & $\begin{array}{c}\mathrm{FHB}^{\mathrm{w}} \\
\text { incidence } \\
(\%)\end{array}$ & $\begin{array}{c}\text { FHB } \\
\text { severity } \\
(\%)\end{array}$ & $\begin{array}{c}\mathrm{DON}^{\mathrm{x}} \\
\left(\mathrm{mg} \mathrm{kg}^{-1}\right)\end{array}$ \\
\hline \multicolumn{5}{|l|}{ Ottawa 2001} \\
\hline Two-row spike, purple lemma & 86 & $6.7 \mathrm{a}^{\mathrm{y}}$ & $\ldots{ }^{\mathrm{z}}$ & $3.9 \mathrm{a}$ \\
\hline Two-row spike, yellow lemma & 9 & $6.0 \mathrm{a}$ & $\ldots$ & $3.1 \mathrm{a}$ \\
\hline Six-row spike, purple lemma & 13 & $16.0 \mathrm{~b}$ & $\ldots$ & $10.6 \mathrm{~b}$ \\
\hline Six-row spike, yellow lemma & 82 & $20.1 \mathrm{~b}$ & $\ldots$ & $13.2 \mathrm{~b}$ \\
\hline \multicolumn{5}{|l|}{ Ottawa 2002} \\
\hline Two-row spike, purple lemma & 86 & $5.7 \mathrm{a}$ & $\ldots$ & $2.7 \mathrm{a}$ \\
\hline Two-row spike, yellow lemma & 9 & $15.1 \mathrm{~b}$ & $\ldots$ & $3.7 \mathrm{a}$ \\
\hline Six-row spike, purple lemma & 13 & $15.6 \mathrm{~b}$ & $\ldots$ & $9.2 \mathrm{~b}$ \\
\hline Six-row spike, yellow lemma & 82 & $29.9 \mathrm{c}$ & $\ldots$ & $6.9 \mathrm{~b}$ \\
\hline \multicolumn{5}{|l|}{ Charlottetown 2002} \\
\hline Two-row spike, purple lemma & 86 & $\ldots$ & $\ldots$ & $13.4 \mathrm{a}$ \\
\hline Two-row spike, yellow lemma & 9 & $\ldots$ & $\ldots$ & $10.8 \mathrm{a}$ \\
\hline Six-row spike, purple lemma & 13 & $\ldots$ & $\ldots$ & $20.5 \mathrm{~b}$ \\
\hline Six-row spike, yellow lemma & 82 & $\ldots$ & $\ldots$ & $19.8 \mathrm{~b}$ \\
\hline \multicolumn{5}{|l|}{ Hangzhou 2001} \\
\hline Two-row spike, purple lemma & 85 & $42.7 \mathrm{a}$ & $11.2 \mathrm{a}$ & $\ldots$ \\
\hline Two-row spike, yellow lemma & 9 & $73.0 \mathrm{~b}$ & $19.8 \mathrm{~b}$ & $\ldots$ \\
\hline Six-row spike, purple lemma & 13 & $83.7 \mathrm{~b}$ & $27.6 \mathrm{c}$ & $\ldots$ \\
\hline Six-row spike, yellow lemma & 82 & $94.1 \mathrm{c}$ & $31.9 \mathrm{~d}$ & $\ldots$ \\
\hline \multicolumn{5}{|l|}{ Hangzhou 2002} \\
\hline Two-row spike, purple lemma & 83 & $42.8 \mathrm{a}$ & $8.2 \mathrm{a}$ & $\ldots$ \\
\hline Two-row spike, yellow lemma & 9 & $81.5 \mathrm{~b}$ & $16.1 \mathrm{~b}$ & $\ldots$ \\
\hline Six-row spike, purple lemma & 13 & $79.9 \mathrm{~b}$ & $25.9 \mathrm{c}$ & $\ldots$ \\
\hline Six-row spike, yellow lemma & 76 & $89.7 \mathrm{~b}$ & $28.2 \mathrm{c}$ & $\ldots$ \\
\hline
\end{tabular}

${ }^{\mathrm{w}} \mathrm{FHB}=$ Fusarium head blight.

${ }^{x}$ DON = deoxynivalenol content.

${ }^{y}$ Means at each location in each year followed by different letters are significantly different at $P=0.05$ based on the least significant difference.

Not determined.

\section{DISCUSSION}

Spike type. Unlike our study, Chełkowski et al. (2) found no significant differences in NIV and DON content between two-row and six-row DH lines. On the other hand, Urrea et al. (20) and Mesfin et al. (15) reported that the two-row allele (vrsl.b) is associated with low DON. In our study, the two-row type is controlled by the deficiens allele (vrs1.t) and thus lateral florets are absent. Therefore, these studies indicate that both vrs $1 . b$ and vrs 1.t alleles are associated with lower FHB infection and DON contamination. One of the DH lines in our study, by chance, did have fertile lateral florets, but its other spike characteristics (such as purple lemma, long rachilla hairs, rough lemma awn, and long glume awn) looked like its two-row parent CI9831. The DON content of this line $\left(5.0 \mathrm{mg} \mathrm{kg}^{-1}\right.$ at Ottawa in 2001, $4.4 \mathrm{mg} \mathrm{kg}^{-1}$ at Ottawa in 2002, and $19.4 \mathrm{mg} \mathrm{kg}^{-1}$ at Charlottetown) was higher than the mean of 95 two-row lines, while its FHB incidence (35\% at Hangzhou in 2001 and $2.8 \%$ at Hangzhou in 2002) was lower than the mean. Zhu et al. (21) did find that the infertile lateral florets (int-c) reduced FHB and DON accumulation. The two-row type is probably more resistant to FHB than the six-row type because two-row spikes dry faster and it is more difficult for the pathogen to spread upward and downward (2). The seed size and seed weight of these two-row lines are greater than those of sixrow lines $(8,10)$. Therefore, the large kernels of two-row lines could have diluted the DON concentration, which in turn, contribute to an additional reduction in DON content for two-row barley. In this study, two-row lines were also taller, but more resistant to lodging. They headed significantly earlier at Hangzhou, but not at Ottawa and Charlottetown. The tall stature and lodging resistance could also have contributed to the reduced level of FHB infection of two-row lines.

Glume awn. Sixteen to seventeen of the 116 long-glumeawned lines contained the least amount of DON, but 6 to 9 of
TABLE 5. Correlation coefficients for two-row and six-row barley lines derived from a Léger $\times$ CI9831 cross $^{\mathrm{x}}$

\begin{tabular}{lll}
\hline Traits & Two-row & Six-row \\
\hline Ottawa 2001 & & \\
Heading \& DON & -0.06 & -0.11 \\
Height \& DON & $-0.34^{* *}$ & $-0.49^{* *}$ \\
Lodging \& DON & $0.57^{* *}$ & $0.51^{* *}$ \\
FHBz incidence \& DON & $0.64^{* *}$ & $0.71^{* *}$ \\
Ottawa 2002 & & \\
Heading \& DON & -0.14 & -0.18 \\
Height \& DON & $-0.48^{* *}$ & $-0.26^{*}$ \\
Lodging \& DON & 0.01 & $0.26^{* *}$ \\
FHB incidence \& DON & $0.58^{* *}$ & $0.37^{* *}$ \\
Charlottetown 2002 & & \\
Heading \& DON & 0.19 & $0.42^{* *}$ \\
Hangzhou 2001 & & \\
Heading \& FHB incidence & -0.00 & 0.18 \\
Height \& FHB incidence & -0.14 & 0.13 \\
FHB severity \& FHB incidence & $0.98^{* *}$ & $0.76^{* *}$ \\
Hangzhou 2002 & & \\
Heading \& FHB incidence & 0.00 & 0.05 \\
Height \& FHB incidence & $-0.23^{*}$ & -0.18 \\
FHB severity \& FHB incidence & $0.77^{* *}$ & $0.68^{* *}$ \\
\hline x $*$ and ** indicate significantly different from zero at $P=0.05$ and 0.01, \\
respectively. & & \\
y DON = deoxynivalenol content. & & \\
z FHB = Fusarium head blight. & & \\
& &
\end{tabular}

them also contained the highest amount of DON (Table 6). In comparison, 16 to 19 of the 95 two-row lines contained the least amount of DON and only 2 of them contained the highest amount of DON (Table 6). Therefore, the association between long glume awn and low DON content is most likely due to genetic linkages rather than pleiotropy. The Lga locus is located in the region between the two restriction fragment length polymorphism markers WG789A and MWG836 on chromosome 7HS and it is closer to MWG836 (5.1 cM) than to WG789A (20.4 cM) (11). The WG789A-MWG836 region in cv. Chevron has been reported to be associated with low FHB severity and low DON content (13). The region between MWG836 and ABG476 in Chevron has also been found to be associated with low DON content, high FHB severity, late heading, and tall plants (5). In our study, the Lga allele of the resistant parent CI9831 was associated with low DON content at both Ottawa and Charlottetown, and it was also associated with late heading at Ottawa in 2001 and with tall plants at Ottawa in 2002. Therefore, our results appear to support the early finding that chromosome 7HS carries QTL for resistance to FHB infection and DON accumulation $(5,13)$.

Lemma color. The low level of FHB incidence in purple lines could be due to the presence of a high level of phenolic compounds, some of which can inhibit FHB development (18). Purple lines of this population, however, contain a similar amount of lignin as yellow lines (4). In addition to the possibility of pleiotropy, linkages with QTL for FHB resistance could also be a factor for the reduction of FHB in purple lines. Zhu et al. (21) detected one major QTL for FHB resistance on chromosome $2 \mathrm{H}$ in one mapping population. Mesfin et al. (15) identified three major QTL for FHB resistance on chromosome $2 \mathrm{H}$ in another mapping population.

Rachilla hairs and lemma awn. It appears that the region surrounding the srh and rawl loci on chromosome $5 \mathrm{H}$ does not carry QTL for FHB resistance. Urrea et al. (20) also found no association between rough awn and FHB severity.

Heading date. The maximum difference in heading date for these DH lines ranged from 11 to 30 days in the five tests (Table 2 ). The growing conditions at the three locations varied greatly, with barley being grown as a summer crop at Ottawa and Charlottetown and as a winter crop at Hangzhou. The inoculation methods, time of inoculation, and isolates used at the three locations were not the same. Still, we were not able to detect any cor- 


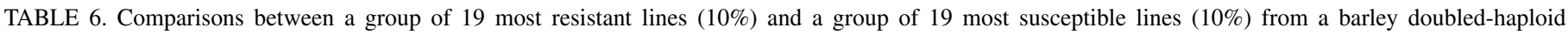
population derived from a Léger $\times$ CI9831 cross

\begin{tabular}{|c|c|c|c|c|c|c|c|c|c|c|}
\hline \multirow[b]{2}{*}{ Group } & $\begin{array}{l}\text { Two-row } \\
\text { spike }\end{array}$ & $\begin{array}{l}\text { Purple } \\
\text { lemma }\end{array}$ & $\begin{array}{l}\text { Long rachilla } \\
\text { hairs }\end{array}$ & $\begin{array}{c}\text { Rough } \\
\text { awn }\end{array}$ & $\begin{array}{c}\text { Long } \\
\text { glume awn }\end{array}$ & \multirow{2}{*}{$\begin{array}{l}\text { Heading } \\
\text { (days) }\end{array}$} & \multirow{2}{*}{$\begin{array}{l}\text { Height } \\
\text { (cm) }\end{array}$} & \multirow{2}{*}{$\begin{array}{l}\text { Lodging } \\
\quad(0-9)\end{array}$} & \multirow{2}{*}{$\begin{array}{c}\text { FHB }^{\mathrm{q}} \\
\text { incidence }(\%)\end{array}$} & \multirow{2}{*}{$\begin{array}{c}\mathrm{DON}^{\mathrm{r}} \\
\left(\mathrm{kg} \mathrm{mg}^{-1}\right)\end{array}$} \\
\hline & \multicolumn{5}{|c|}{ Number of lines } & & & & & \\
\hline \multicolumn{11}{|l|}{ Ottawa 2001} \\
\hline Most resistant ${ }^{\mathrm{s}}$ & $16 \mathrm{a}^{\mathrm{t}}$ & $15 \mathrm{a}^{\mathrm{t}}$ & $11 \mathrm{a}^{\mathrm{t}}$ & $9 \mathrm{a}^{\mathrm{t}}$ & $17 \mathrm{a}^{\mathrm{t}}$ & $55 \mathrm{c}^{\mathrm{u}}$ & $131 c^{u}$ & $1.5 \mathrm{c}^{\mathrm{u}}$ & $3.2 \mathrm{c}^{\mathrm{u}}$ & $0.7 \mathrm{c}^{\mathrm{u}}$ \\
\hline Most susceptible ${ }^{v}$ & $2 \mathrm{~b}$ & $5 \mathrm{~b}$ & $6 a$ & $9 \mathrm{a}$ & $7 \mathrm{~b}$ & $53 \mathrm{~d}$ & $112 \mathrm{~d}$ & $5.2 \mathrm{~d}$ & $25.6 \mathrm{~d}$ & $32.6 \mathrm{~d}$ \\
\hline \multicolumn{11}{|l|}{ Ottawa 2002} \\
\hline Most resistant ${ }^{\mathrm{s}}$ & $19 \mathrm{a}$ & $17 \mathrm{a}$ & $7 \mathrm{a}$ & $8 \mathrm{a}$ & $16 \mathrm{a}$ & $53 \mathrm{c}$ & $105 \mathrm{c}$ & $0.1 \mathrm{c}$ & $4.0 \mathrm{c}$ & $0.9 \mathrm{c}$ \\
\hline Most susceptible ${ }^{v}$ & $2 b$ & $5 \mathrm{~b}$ & $9 \mathrm{a}$ & $11 \mathrm{a}$ & $6 \mathrm{~b}$ & $53 \mathrm{c}$ & $87 \mathrm{~d}$ & $0.8 \mathrm{~d}$ & $31.4 \mathrm{~d}$ & $16.7 \mathrm{~d}$ \\
\hline \multicolumn{11}{|l|}{ Charlottetown 2002} \\
\hline Most resistant $\mathrm{s}^{\mathrm{s}}$ & $16 \mathrm{a}$ & $15 \mathrm{a}$ & $14 \mathrm{a}$ & $9 \mathrm{a}$ & $16 \mathrm{a}$ & $49 \mathrm{c}$ & $\ldots{ }^{\mathrm{w}}$ & $\ldots$ & $\ldots$ & $4.9 \mathrm{c}$ \\
\hline Most susceptible ${ }^{v}$ & $2 b$ & $5 \mathrm{~b}$ & $6 \mathrm{~b}$ & $9 a$ & $9 \mathrm{~b}$ & $52 \mathrm{~d}$ & $\ldots$ & $\ldots$ & $\ldots$ & $38.2 \mathrm{~d}$ \\
\hline \multicolumn{11}{|l|}{ Hangzhou 2001} \\
\hline Most resistant ${ }^{\mathrm{x}}$ & $19 \mathrm{a}$ & $18 \mathrm{a}$ & $13 \mathrm{a}$ & $12 \mathrm{a}$ & $14 \mathrm{a}$ & $123 \mathrm{c}$ & $122 \mathrm{c}$ & $0.0 \mathrm{c}$ & $6.3 \mathrm{c}$ & $\ldots$ \\
\hline Most susceptible ${ }^{y}$ & $0 \mathrm{~b}$ & $1 \mathrm{~b}$ & $9 \mathrm{a}$ & $10 \mathrm{a}$ & $7 \mathrm{a}$ & $124 \mathrm{c}$ & $117 \mathrm{c}$ & $0.0 \mathrm{c}$ & $37.0 \mathrm{~d}$ & $\ldots$ \\
\hline \multicolumn{11}{|l|}{ Hangzhou 2002} \\
\hline Most resistant $\mathrm{x}^{\mathrm{xz}}$ & $18 \mathrm{a}$ & $18 \mathrm{a}$ & $11 \mathrm{a}$ & $11 \mathrm{a}$ & $13 \mathrm{a}$ & $139 \mathrm{c}$ & $104 \mathrm{c}$ & $0.0 \mathrm{c}$ & $17.0 \mathrm{c}$ & $\ldots$ \\
\hline Most susceptible ${ }^{\mathrm{yz}}$ & $3 \mathrm{~b}$ & $4 \mathrm{~b}$ & $9 \mathrm{a}$ & $11 \mathrm{a}$ & $9 \mathrm{a}$ & $142 \mathrm{c}$ & $98 \mathrm{~d}$ & $0.0 \mathrm{c}$ & $98.5 \mathrm{~d}$ & $\cdots$ \\
\hline \multicolumn{11}{|c|}{ q FHB = Fusarium head blight. } \\
\hline \multicolumn{11}{|c|}{ DON = deoxynivalenol content. } \\
\hline \multicolumn{11}{|c|}{ Indicates lowest DON accumulation. } \\
\hline \multicolumn{11}{|c|}{ Numbers followed by different letters in each test are significantly different at $P=0.05$ when compared with the $\chi^{2}$ test. } \\
\hline \multicolumn{11}{|c|}{ u Means followed by different letters in each test are significantly different at $P=0.05$ based on the $t$ test. } \\
\hline \multicolumn{11}{|c|}{ v Indicates highest DON accumulation. } \\
\hline \multicolumn{11}{|c|}{ w Not determined. } \\
\hline \multicolumn{11}{|c|}{$\mathrm{x}$ Indicates lowest FHB incidence. } \\
\hline \multicolumn{11}{|c|}{ y Indicates highest FHB incidence. } \\
\hline z Each group consis & 18 lines $(1$ & only. & & & & & & & & \\
\hline
\end{tabular}

relation between heading date and DON content (or FHB incidence) in 9 of the 10 cases, indicating that QTL for heading date are not closely linked with QTL for FHB or DON content in this $\mathrm{DH}$ population. Zhu et al. (21) also found no correlation between heading date and FHB resistance in their population. These results are in contrast with other studies. de la Pena et al. (5) found a negative correlation between heading date and DON content at Crookston (Minnesota) and a positive correlation in Hangzhou. Likewise, Mesfin et al. (15) found the correlation negative in four environments and positive in another environment. The correlations obtained from the studies of Ma et al. (13) and Urrea et al. (20) were mostly negative.

Plant height and lodging resistance. All four correlation coefficients between plant height and DON content at Ottawa were negative, but only one correlation coefficient between plant height and FHB incidence at Hangzhou was negative (Table 5). This could be due to the inoculation methods used at the two locations. The plots at Ottawa were broadcast with infected grains, but those at Hangzhou were first broadcast with infected grains and then sprayed with an $F$. graminearum suspension. Therefore, tall barley could be subjected to less disease pressure than short barley at Ottawa but to only slightly less disease pressure at Hangzhou. Many other researcher $(5,13,20)$ observed negative correlation coefficients between plant height and DON content in their populations. Barley with its height reduced by a growth regulator had higher FHB incidence than the untreated control (14). As pointed out by Ma et al. (13), tall plants are further away from Fusarium inoculum on the ground and further away from the soil moisture. Under small plot conditions, heads of tall plants do not have any protection from wind from neighboring plots and thus they dry faster than those of short plants. Consequently, the microenvironmental conditions surrounding the heads of tall plant are less favorable for Fusarium inoculum to grow and spread. Lodged plants, just like short plants, are exposed to a microenvironment very favorable for Fusarium species to grow and spread and they consequently accumulate more DON in their kernels. Lodging is not uncommon in the Fusarium nursery because an adequate and constant supply of moisture is provided to promote FHB development. The con- founding effect of plant height and lodging on FHB development is very difficult to eliminate in the field. One possible way to overcome the problem is to apply growth regulators to shorten the plant height and to reduce lodging. The choice of growth regulators is critical because some, such as ancymidol, may inhibit mycotoxin production (6).

FHB incidence. This and other studies $(5,13,15,20,21)$ showed a positive correlation between FHB severity and DON content. Therefore, visual scoring of FHB symptom can be used as an indirect selection for low DON content.

In summary, the results of this study showed that resistance to FHB and DON accumulation is associated with two-row spike, purple lemma, long glume awn, tall stature, and resistance to lodging and that there is no association with long rachilla hairs, rough lemma awn, and heading date. The results suggest that trait association should be taken into consideration when breeding for FHB resistance and interpreting data from FHB experiments. To our knowledge, this is the first report on the effects of the deficiens two-row, purple lemma, long glume awn, long rachilla hairs, and lodging on FHB and DON accumulation in barley.

\section{ACKNOWLEDGMENTS}

We thank K. McRae, F. Sabo, S. Buffam, D. Murphy, M. Kuc, and R. Matters for their assistance in conducting this study.

\section{LITERATURE CITED}

1. Campbell, H., Choo, T. M., Vigier, B., and Underhill, L. 2002. Comparison of mycotoxin profiles among cereal samples from eastern Canada. Can. J. Bot. 80:526-532.

2. Chełkowski, J., Wiśniewska, H., Adamski, T., Goliński, P., Kaczmarek, Z., Kostecki, M., Perlowski, J., and Surma, M. 2000. Effects of Fusarium culmorum head blight on mycotoxin accumulation and yield traits in barley doubled haploids. J. Phytopathol. 148:541-545.

3. Choo, T. M., Ho, K. M., Konishi, T., and Martin, R. A. 1992. Tests for randomness among doubled haploid lines derived by the bulbosum method in barley (Hordeum vulgare L.). SABRAO J. 24:87-92.

4. Choo, T. M., Vigier, B., Ho, K. M., Ceccarelli, S., Grando, S., and Franckowiak, J. D. 2005. Comparison of black, purple, and yellow barleys. Gen. Res. Crop Evol. (In Press.) 
5. de la Pena, R. C., Smith, K. P., Capettini, F., Muehlbauer, G. J., GalloMeagher, M., Dill-Macky, R., Somers, D. A., and Rasmusson, D. C. 1999. Quantitative trait loci associated with resistance to Fusarium head blight and kernel discoloration in barley. Theor. Appl. Genet. 99:561-569.

6. Desjardins, A. E., Platter, R. D., and Beremand, M. N. 1987. Ancymidol blocks trichothecene biosynthesis and leads to accumulation of trichodiene in Fusarium sporotrichioides and Gibberella pulicaris. Appl. Environ. Microbiol. 53:1860-1865.

7. Frégeau-Reid, J., Choo, T. M., Ho, K. M., Martin, R. A., and Konishi, T. 2001. Comparisons of two-row and six-row barley for chemical composition using doubled-haploid lines. Crop Sci. 41:1737-1743.

8. Frégeau-Reid, J., Choo, T. M., Jui, P., and Ho, K. M. 1996. Inheritance of kernel size and shape of barley. SABRAO J. 28:47-55.

9. Ho, K. M., Tekauz, A., Choo, T. M., and Martin, R. A. 1996. Genetic studies on net blotch resistance in a barley cross. Can. J. Plant Sci. 76:715-719.

10. Jui, P. Y., Choo, T. M., Ho, K. M., Konishi, T., and Martin, R. A. 1997. Genetic analysis of a two-row $\times$ six-row cross of barley using doubled-haploid lines. Theor. Appl. Genet. 94:549-556.

11. Kleinhofs, A., and Han, F. 2002. Molecular mapping of the barley genome. Pages 31-63 in: Barley Science: Recent Advances from Molecular Biology to Agronomy of Yield and Quality. G. A. Slafer, J. L. Molina-Cano, R. Savin, J. L. Araus, and I. Romagosa, eds. Food Products Press, New York.

12. Lebowitz, R. L., Soller, M., and Beckmann, J. S. 1987. Trait-based analysis for the detection of linkage between marker loci and quantitative trait loci in crosses between inbred lines. Theor. Appl. Genet. 73:556-562.

13. Ma, Z., Steffenson, B. J., Prom, L. K., and Lapitan, L. A. 2000. Mapping of quantitative trait loci for Fusarium head blight resistance in barley. Phytopathology 90:1079-1088.

14. Martin, R. A., Macleod, J. A., and Caldwell, C. 1991. Influences of production inputs on incidence of infection by Fusarium species on cereal seed. Plant Dis. 75:784-788.

15. Mesfin, K. P., Smith, K. P., Dill-Macky, R., Evans, C. K., Waugh, R., Gustus, C. D., and Muehlbauer, G. J. 2003. Quantitative traits loci for Fusarium head blight resistance in barley detected in a two-rowed by sixrowed population. Crop Sci. 43:307-318.

16. Sinha, R. C., and Savard, M. E. 1996. Comparison of immunoassay and gas chromatography methods for the detection of the mycotoxin deoxynivalenol in grain samples. Can. J. Plant Pathol. 18:233-236.

17. Sinha, R. C., Savard, M. E., and Lau, R. 1995. Production of monoclonal antibodies for the specific detection of deoxynivalenol and 15acetyldeoxynivalenol by ELISA. J. Agric. Food Chem. 43:1740-1744.

18. Skadhauge, B., Thomsen, K. K., and von Wettstein, D. 1997. The role of barley testa layer and its flavonoid content in resistance to Fusarium infections. Hereditas 126:147-160.

19. Steel, R. G. D., and Torrie, J. H. 1960. Principles and Procedures of Statistics. McGraw-Hill Book Co., New York.

20. Urrea, C. A., Horsley, R. D., Stefenson, B. J., and Schwarz, P. B. 2002. Heritability of Fusarium head blight resistance and deoxynivalenol accumulation from barley accession Ciho 4196. Crop Sci. 42:1404-1408.

21. Zhu, H., Gilchrist, L., Hayes, P., Kleinhofs, A., Kudrna, D., Liu, Z., Prom, L., Steffenson, B., Toojinda, T., and Vivar, H. 1999. Does function follow form? Principal QTLs for Fusarium head blight (FHB) resistance are coincident with QTLs for inflorescence traits and plant height in a doubled-haploid population of barley. Theor. Appl. Genet. 99:1221-1232. 